\title{
The Urgency of Legal Literacy for Indonesian Migrant Workers through Distance Education
}

\section{Eny Kusdarini ${ }^{1}$, Chandra Dewi Puspitasari ${ }^{2}$, Sri Wahyu Krida Sakti ${ }^{3}$, Purwaningdyah Murti Wahyuni ${ }^{4}$}

\author{
${ }^{1}$ Universitas Negeri Yogyakarta, Indonesia, \\ E-mail:eny_kusdarini@uny.ac.id \\ ${ }^{2}$ Universitas Negeri Yogyakarta, Indonesia, \\ E-mail: chandradewi@uny.ac.id \\ ${ }^{3}$ Universitas Terbuka, Indonesia \\ E-mail: sriwahyu@ecampus.ut.ac.id \\ ${ }^{4}$ Universitas Terbuka, Indonesia \\ E-mail: purwaningdyah@ecampus.ut.ac.id
}

Submitted: February 5, 2021; Reviewed: May 18, 2021; Accepted: June 28, 2021

\begin{tabular}{|c|c|}
\hline Article Info & Abstract \\
\hline $\begin{array}{l}\text { Keywords: } \\
\text { Legal literacy, Indonesian migrant } \\
\text { workers, distance education. } \\
\text { DOI: } \\
\text { 10.25041/fiatjustisia.v15no4.2317 }\end{array}$ & $\begin{array}{l}\text { Protection for migrant workers requires } \\
\text { intervention throughout the migration cycle. } \\
\text { Moreover, it raises awareness about safe migration } \\
\text { before departure, ensuring effective migration } \\
\text { policies and mechanisms, ensuring fair recruitment } \\
\text { practices, decent working conditions in destination } \\
\text { countries, and economic empowerment and } \\
\text { reintegration to the home community for retired } \\
\text { Indonesian Migrant Workers. However, illegal } \\
\text { hiring practices can leave workers trapped in debt- } \\
\text { bound situations to go abroad. Often workers are } \\
\text { not appropriately trained and do not understand } \\
\text { their rights, so they are easily exploited. So the } \\
\text { problem arises in this study how to fulfil the legal } \\
\text { protection of Indonesian migrant workers? And how } \\
\text { can legal literacy improve the protection of } \\
\text { Indonesian migrantworkers? The study results show } \\
\text { that Indonesian migrant workers need state } \\
\text { intervention to protect the stage before work, during } \\
\text { work, and after work but also need to equip } \\
\text { themselves with qualified legal insight. The qualified } \\
\text { legal insight will increase the capacity of Indonesian } \\
\text { migrant workers and will enable them to face every } \\
\text { problem they face. Legal literacy is an urgent matter } \\
\text { to be "familiarized" with Indonesian migrant } \\
\text { workers. Legal literacy will build awareness of } \\
\text { Indonesian migrant workers in understanding } \\
\text { various legal aspects, especially those related to the } \\
\text { activities of Indonesian migrant workers. Distance }\end{array}$ \\
\hline
\end{tabular}


education can be a way to improve the legal literacy

of Indonesian migrant workers.

\section{A. Introduction}

Manpower development in Indonesia is inseparable from the state's efforts to create Indonesian people entirely to enhance the dignity of the workforce. ${ }^{1}$ Besides that, it is also to realize creating a prosperous and fair society, both spiritually and materially. The alternative of working abroad is an option for the Indonesian government to overcome labor problems, driving labor migration. ${ }^{2}$

From a historical point of view, labor migration is not new. However, labor migration has always been an interesting issue in the world of global employment. Labor migration can affect many countries, both sending and receiving countries. ${ }^{3}$ Todaro (1992) describes the migration theory formulated by Lewis (1954) about rural-urban labor migration, which is then classified as a migrant worker. ${ }^{4}$ The ILO (International Labor Organization) states that a migrant worker has migrated from one country to another, illustrating that the person will be employed by someone who is not himself, including anyone who is usually recognized as a migrant to work. ${ }^{5}$

Labor migration is a challenge in itself for sending and destination countries. One of Indonesia's challenges as a sending country for migrant workers to destination countries lies in protecting Indonesian migrant workers. ${ }^{6}$ The complexity of Indonesia's labor problem is partly due to the lack of adequate protection for the migrant sector. ${ }^{7}$ Legal protection for migrant workers by the state is part of legal protection for citizens. The provisions of Article $28 \mathrm{D}$ paragraph (1) and paragraph (2) of the 1945

\footnotetext{
${ }^{1}$ Dahlia, "Pelaksanaan Program Jamsostek Ditinjau Dari Perspektif Perlindungan Hukum Tenaga Kerja," Jurnal Wacana Hukum 11, no. 1 (2012): 83-94, https://doi.org/10.33061/1.jwh.2012.11.1.732.

${ }^{2}$ Suhartoyo, "Prinsip Persiapan Penempatan Dan Perlindungan Tenaga Kerja Indonesia Di Luar Negeri," Adminitrative Law \& Governance Journal 2, no. 3 (2019): 523-40, https://doi.org/10.14710/alj.v2i3.523-540.

${ }^{3}$ Haryono, "Globalisasi Dan Migrasi Tenaga Kerja Indonesia (Studi Deskriptif Sosiologi Kependudukan)," Hermeneutika: Jurnal Hermeneutika 3, no. 2 (2017): 1-13, https://doi.org/10.30870/hermeneutika.v3i2.3084.

${ }^{4}$ Didit Purnomo, "Fenomena Migrasi Tenaga Kerja Dan Perannya Bagi Pembangunan Daerah Asal: Studi Empiris Di Kabupaten Wonogiri," Jurnal Ekonomi Pembangunan 10, no. 1 (2009): 84-102, https://doi.org/10.23917/jep.v10i1.810.

5 International Labor Organization (ILO), "Perlindungan Dan Pencegahan Untuk Pekerja Migran Indonesia," 2006, https://www.ilo.org/jakarta/whatwedo/publications/WCMS_122318/lang--en/index.htm.

${ }^{6}$ A. A. Titah Ratihtiari and I Wayan Parsa, "Perlindungan Hukum Terhadap Pekerjamigran Indonesia Di Luar Negeri," Kertha Semaya 7, no. 7 (2019): 1-15, https://doi.org/10.24843/KM.2019.v07.i07.p02.

${ }^{7}$ Zulfikar Judge, "Perlindungan Hukum Bagi Tenaga Kerja Indonesia Di Luar Negeri," Lex $\begin{array}{lllll}\text { Jurnalica } & 9, & \text { no. } & 3 & \text { (2012): }\end{array}$
} https://ejurnal.esaunggul.ac.id/index.php/Lex/article/view/347. 
Constitution of the Republic of Indonesia state: "Everyone has the right to recognition, guarantee, protection and legal certainty that is just and equal treatment before the law" (paragraph 1) and "Everyone has the right to work and to receive compensation and fair and proper treatment in an employment relationship" (paragraph 2). ${ }^{8}$ Based on this provision, the Indonesian government must protect Indonesian Migrant Workers or Pekerja Migran Indonesia (PMI).

Indonesian Migrant Workers or PMI are every Indonesian citizens who will be, are currently doing, or work with wages outside the Republic of Indonesia's territory. ${ }^{9}$ The Human Capital Index (HCI) places Indonesia at the 87th or 6th place in Southeast Asia to affect the quality of PMI. ${ }^{10}$ According to the International Labour Organization (ILO), in 2015, in the placement of migrant workers abroad, among ASEAN countries, Indonesia is known as the second country after the Philippines. This condition shows how important it is to discuss the phenomenon of international migration, which has become part of the economic and social life of the world's population. Economic factors, in search of a job and a better life, are important reasons for migration. ${ }^{11}$ Data shows that from 2014 to 2019, PMI amounted to 1.55 million workers. They were scattered in various countries, especially in Malaysia, Taiwan, and Hong Kong. In the first quarter of 2019, PMI reached 64,062 workers, consisting of 19,597 (31\%) male and 44,465 (70\%) female workers. ${ }^{12}$

According to data from the World Bank, to date, more than 9 (nine) million Indonesians work abroad, both procedurally and non-procedurally. This figure is equivalent to nearly 7 (seven) per cent of the total workforce. According to the PMI Protection Agency or Badan Pelindungan Pekerja Migran Indonesia (BP2MI) report on PMI placement data, as of 2019, there were 276,553 PMIs.

\footnotetext{
${ }^{8}$ A. Muhammad Asrun, "Hak Asasi Manusia Dalam Kerangka Cita Negara Hukum (Catatan Perjuangan Di Mahkamah Konstitusi)," Jurnal Cita Hukum 4, no. 1 (2016): 133-54, https://doi.org/10.15408/jch.v4i1.3200.2016.4.1.133-154.

${ }^{9}$ Hartono Widodo and R. Jossi Belgradoputra, "Perlindungan Pekerja Migran Indonesia," Binamulia Hukum 8, no. 1 (2019): 107-16, https://doi.org/10.37893/jbh.v8i1.42.

10 Solechan, Tri Rahayu Utami, and Muhamad Azhar, "Upaya Meningkatkan Jaminan Perlindungan Pekerja Migran Indonesia," Administrative Law \& Governance Journal 2, no. 1 (2020): 153-61, https://doi.org/10.14710/alj.v3i1.153-161.

${ }^{11}$ Aswatini Raharto, "Pengambilan Keputusan Tenaga Kerja Indonesia (TKI) Perempuan Untuk Bekerja Di Luar Negeri: Kasus Kabupaten Cilacap," Jurnal Kependudukan Indonesia 12, no. 1 (2017): 39-45, https://doi.org/10.14203/jki.v12i1.275.

12 Databoks, "2014 - Maret 2019, Penempatan Pekerja Migran Capai 1,55 Juta," 2019, https://databoks.katadata.co.id/datapublish/2019/07/30/2014-maret-2019-penempatanpekerja-migran-capai-155-juta.
} 
Table 1. Data on Indonesian Migrant Workers or Pekerja Migran Indonesia (PMI) Placement for 2012-2019

\begin{tabular}{|c|c|c|c|c|c|c|}
\hline No & Year & Total & Female & $\%$ & Male & $\%$ \\
\hline 1 & 2012 & 494.609 & 279.784 & 57 & 214.825 & 43 \\
\hline 2 & 2013 & 512.168 & 276.998 & 54 & 235.170 & 46 \\
\hline 3 & 2014 & 429.872 & 243.629 & 57 & 186.243 & 43 \\
\hline 4 & 2015 & 257.736 & 116.771 & 60 & 108.965 & 40 \\
\hline 5 & 2016 & 234.451 & 145.392 & 62 & 89.059 & 38 \\
\hline 6 & 2017 & 261.820 & 183.561 & 70 & 78.259 & 30 \\
\hline 7 & 2018 & 248.723 & 168.865 & 68 & 79.858 & 32 \\
\hline 8 & $\begin{array}{c}2019 \\
\text { (per September) }\end{array}$ & 276.553 & 191.237 & 69 & 85.316 & 31 \\
\hline
\end{tabular}

Source: Indonesian Migrant Worker Protection Agency or Badan

Perlindungan Pekerja Migran Indonesia (BP2MI) Report 2019

Indonesian migrant workers who work abroad are very vulnerable to various problems, even from before their departure to their return to Indonesia. ${ }^{13}$ This is also based on Koesrianti's research which states that Indonesian workers have a weak position because they come from poor families, have low education, do not understand their rights, and are under economic pressure. ${ }^{14}$ Protection of migrant workers requires intervention throughout the migration cycle, raising awareness about safe migration before departure and ensuring effective migration policies and mechanisms. This protection certainly involves various parties from various Ministries/sectors under their primary duties and function. ${ }^{15}$

It can be said that the problems faced by Indonesian migrant workers are very complicated. Not to mention the issue of Indonesian migrant workers who are recruited through illegal channels. ${ }^{16}$ According to the International Organization for Migration (IOM), people are easily attracted to work abroad, which promises higher wages for the same work in their own country. However, the practice of illegal recruitment can leave workers trapped in debt bondage situations to go abroad. In addition, the workforce is often not

\footnotetext{
${ }^{13}$ Sigit Sepriandi, "Kebijakan Perlindungan Sosial Bagi Pekerja Migran Bermasalah (PMB) Di Debarkasi Kota Tanjungpinang," Kemudi: Jurnal Ilmu Pemerintahan 2, no. 2 (2018): 79-102, https://ojs.umrah.ac.id/index.php/kemudi/article/view/760.

${ }^{14}$ Koesrianti, "Pelindungan Hukum Pekerja Migran Penata Laksana Rumah Tangga (PLRT) Di Luar Negeri Oleh Negara Ditinjau Dari Konsep Tanggung Jawab Negara," Yustisia 4, no. 2 (2015): 245-68, https://doi.org/10.20961/yustisia.v4i2.8642.

${ }^{15}$ Habibullah, Ahmad Juhari, and Lucy Sandra, "Kebijakan Perlindungan Sosial Untuk Pekerja Migran Bermasalah,” Sosio Konsepsia 5, no. 2 (2016): 66-77, https://doi.org/10.33007/ska.v5i2.178.

${ }^{16}$ W Saroinsong, "Penanganan Masalah TKI Ilegal Oleh Pemerintah RI," Indonesian Journal $\begin{array}{llllll}\text { of International Law 5, no. } 433-57 \text {, } & 4 & \text { (2008): }\end{array}$
} http://ijil.ui.ac.id/index.php/home/article/download/483/pdf_367. 402 
adequately trained and does not understand their rights, so they are easily exploited. ${ }^{17}$

Such vulnerability causes Indonesian migrant workers to be very likely to experience violence, harassment, breach of employment contracts, limited freedom of migrant workers, lack of social protection, neglect of health insurance, debt bondage, and other problems. One of them is Sulasih bint Sukiran Sadli, from Demak, Central Java, who works in Saudi Arabia. Sulasih was found in critical condition, unconscious due to her injuries. Based on findings, the employer tortured Sulasih. Her eyes were abused with chlorine water. Her hands were allegedly ironed, and her face was swollen from being beaten by her female employer, the wife of a junior immigration officer in Jeddah. ${ }^{18}$

Reflecting on this case, Sulasih was a victim not only when he was in the destination country but even before his departure to the destination country. Another case that is no less sad happened in Malaysia this time. The victim was Adelina Lisau. Adelina worked as a household assistant and was tortured until she died. In fact, for 2 (two) years of work, Adelina has not received a salary. Ironically, the perpetrator was acquitted by the local court. ${ }^{19}$

The cases that befell Sulasih and Adelina are only 2 (two) examples of the many problems that afflict Indonesian migrant workers. These issues show that efforts are also needed to increase the understanding of Indonesian migrant workers towards protecting migrant workers themselves through legal literacy (legal education), not only literacy towards national labour laws but also against local state laws. So the problem in this research is how to fulfil the legal protection of Indonesian migrant workers? And how can legal literacy improve the protection of Indonesian migrant workers? Through an adequate legal education, the author hopes Indonesian migrant workers will have the provision and "strength" to protect themselves from pre-departure until their return to their homeland.

This paper is a study of some of the data presented in a study entitled "Distance and Open Education for Indonesian Migrant Workers," previously conducted by the author's team. The research method combines several research methods of survey method, document-review, depth-interview, and Focus Group Discussion (FGD) with the results of legal literacy education

17 International Organization for Migration (IOM), "Migrasi Tenaga Kerja Indonesia, Gambaran Umum Migrasi Tenaga Kerja Indonesia Di Beberapa Negara Tujuan Di Asia Dan Timur Tengah," 2010, https://www.iom.int/jahia/webdav/shared/shared/mainsite/published_docs/Final-LM-ReportBahasa-Indonesia.pdf.

${ }^{18}$ Eko Hartono, "Keterlaluan, Penyiksaan Oleh Majikan Perempuan': WNI Di Arab Saudi 'mata Disiram Air Klorin, Tangan Disetrika, Kemaluan Diinjak," BBC News, 2020, https://www.bbc.com/indonesia/dunia-53395540.

${ }^{19}$ BBC, “'Penyiksa TKW' Di Malaysia Dibebaskan: 'Dia Mati Karena Disiksa', Indonesia Akan Terus Upayakan Keadilan Untuk Adelina,” BBC News, 2019, https://www.bbc.com/indonesia/dunia-47996097 . 
academic papers for PMI. The study population involved all PMI stakeholders, $\mathrm{SBMI}^{20}$, Ministry of Manpower, professional academics observing PMI. The 2-category sampling system is applied concerning two different primary data sources: the purposive sampling-1 system applied to the PMI management, professional, academic, and activist (Non-Governmental Organization) group resource persons. Meanwhile, simple random sampling-2 has been applied to the PMI population. These samplings consist of 100 migrant workers spread across the five largest migrant workers, namely Kuala Lumpur, Singapore, Taipei, Riyadh, and Hong Kong (purposive sample areas), whose data has been collected through surveys. Data analysis in this study uses Miles Huberman's Interactive Model Data Analysis. Therefore, methodically, this paper departs from a study with a literature study approach.

\section{B. Discussion}

\section{Literacy and Indonesian Migrant Workers}

Indonesian migrant workers can understand the law through legal awareness education or what is currently known as legal literacy. ${ }^{21}$ Literacy is not new. In simple terms, it is often known to the broader community as "literate". But now, literacy does not just invite people not to be illiterate. In general, the concept of literacy is growing, not only in the ability to read and write but also to understand the information read and do something based on what one understands. In its development, it became known that there was literacy in various aspects, such as information literacy, technology literacy, legal literacy, etc.

The low level of legal literacy of Indonesian migrant workers, which then results in the Indonesian migrant workers' lack of understanding of the law (legal illiteracy), is a different problem. The ILO states that several things make migrant workers vulnerable in destination countries, which is related to legal insight. These are 1) The existence of gender stereotypes and solid occupational segregation in the international labour market; 2) Lack of labour protection and social protection for migrant workers/labourers, 3) There are discriminatory immigration policies, 4) Legal blindness and fear of authorities provoking migrant workers/labourer vulnerability, 5) When there is an interdependent work relationship, the vulnerability is authentic, 6) Ocassionally, migrant workers/labourers find themselves in an individual and isolated work environment, namely migrant domestic workers or plantation workers/labourers, 7) Lack of workers' organizations/migrant workers and a

\footnotetext{
${ }^{20}$ Serikat Buruh Migran Indonesia or Indonesian Union of Migrant Workers.

${ }^{21}$ Sumarsono, Grace Ester Caroline Korompis, and Diana Vanda D. Doda, "Pengaruh Edukasi Melalui Literasi Hukum Terhadap Tindakan Pencegahan Medical Error Pada Perawat Di Rumah Sakit," Indonesian Journal of Public Health and Community Medicine 1, no. 4 (2020): 33-39, https://ejournal.unsrat.ac.id/index.php/ijphcm/article/view/31205. 
lack of representation in labour and employment forums, and 8) Xenophobia (fear of foreigners) and stigmatization. ${ }^{22}$

The legal insight of Indonesian migrant workers must be maximized. The habit of reading and accessing information that is not optimal is why migrant workers are always in a situation that is vulnerable to various problems, both experienced during pre-departure and their return to their homeland. Meanwhile, legal education for Indonesian migrant workers aims to increase the capacity of professional and resilient migrant workers in overcoming practical legal problems that they face according to their needs and job challenges. The indicators of professionalism and resilience have good legal insight into carrying out work tasks, being competent in their field of work with high professional ethics, mastering intercultural values, and practically mastering legal norms related to migrant worker issues.

\section{The Problems of Indonesian Migrant Workers}

Bank Indonesia noted that since 2013, these Indonesian migrant workers had sent approximately USD 7 billion to Indonesia each year. Thus, international migration makes a significant contribution to the Indonesian economy. In 2019, the World Bank reported that the wages earned by Indonesian migrant workers amounted to USD 11.67 billion or equivalent to 166.36 trillion IDR. The following is the data on remittances from 2012 to 2019.

Table 2. Results of Remittances for 2012 to 2019

\begin{tabular}{|c|c|c|}
\hline No & Year & $\begin{array}{c}\text { Remittance } \\
\text { (in the US \$ million) }\end{array}$ \\
\hline 1 & 2012 & 7,21 \\
\hline 2 & 2013 & 7,61 \\
\hline 3 & 2014 & 8,55 \\
\hline 4 & 2015 & 9,65 \\
\hline 5 & 2016 & 8,90 \\
\hline 6 & 2017 & 8,76 \\
\hline 7 & 2018 & 10,97 \\
\hline 8 & 2019 & 11,7 \\
\hline
\end{tabular}

Source: Indonesian Migrant Worker Protection Agency or Badan

Perlindungan Pekerja Migran Indonesia (BP2MI) Report 2019

With the figures mentioned above, it is not an exaggeration if many parties still see the placement of Indonesian migrant workers as an opportunity to

${ }^{22}$ International Labor Organization (ILO), "Perlindungan Dan Pencegahan Untuk Pekerja Migran Indonesia." 
solve the unemployment problem in Indonesia. Remittances sent by Indonesian migrant workers to their families should boost their welfare level from an economic perspective. However, the PMI problem's complexity needs to be seriously considered more than just a tool to improve economic statistics. As we know, in general, news about violations of the rights of Indonesian migrant workers, both labour rights violations and non-employment violations, are still rife, especially to Indonesian women migrant workers who work in the informal sector. Therefore, the existence of Indonesian migrant workers does have a positive effect on the country's economy and the economy of the migrant workers' families themselves. However, the placement of Indonesian migrant workers often has intertwined social and legal effects.

National Agency for Placement and Protection of Indonesian Workers or Badan Nasional Penempatan dan Perlindungan Tenaga Kerja Indonesia (BNP2TKI) in 2014 noted that of the 200-400 thousand Indonesian migrant workers who returned to Indonesia, 5\%-15\% had problems. Types of problems experienced include the legality of departure, victims of violence or conflicts with employers, sexual harassment, and payroll. The Ministry of Foreign Affairs noted that from January 1 to September 30, 2014, there were several types of cases experienced by migrant workers abroad, namely 1,785 cases related to employment (salary, work accidents, heavy workload, work termination). 6,610 cases related to immigration matters (overstay, visa abuse) and 23 civil cases (divorce, custody of children). In addition, there were also other cases, namely 816 cases related to criminal acts (drugs, murder, robbery, human trafficking, etc.) and 2273 cases such as loss of contact, death, illness, natural disasters, political unrest, etc. ${ }^{23}$ Meanwhile, the data on cases submitted to the Indonesian Migrant Workers Union (SBMI) shows that during 2016-2017, there was an increase in cases of contractual violations by 1,501 cases. In addition, migrant workers also experience cases of abuse, trafficking, and illness. Furthermore, media monitoring conducted by the Network of Organizations and the Indonesian Migrant Workers Alliance (JBMI) also shows, during 2017, there were cases of undocumented migrant workers (6,300 cases), cases of trafficking in persons (1,083 people), and cases of migrant workers who died. (217 people). ${ }^{24}$

Based on data from the Indonesian Migrant Workers Union, since 20152019, it has handled 1927 cases. Women experience 68\% of Indonesian migrant workers, and men experience $32 \%$ of Indonesian migrant workers. $67 \%$ of Indonesian migrant workers' work problems are Domestic Workers, $13 \%$ factory operators, $6 \% \mathrm{ABK}, 3 \%$ plantations, $3 \%$ elderly nurses, $3 \%$

\footnotetext{
${ }^{23}$ W. Mulyana and Marjuki., "Penanganan Tenaga Kerja Indonesia Bermasalah Melalui Rehabilitasi Psikososial Dan Pemberdayaan Sosial," Kementerian Sosial, 2015, https://www.kemsos.go.id/modules.php?name=News\&file=article\&sid=18580.

24 Indiana Malia, "Kasus Pekerja Migran Meningkat, Ini Penyebabnya," IDN Times, 2018, https://www.idntimes.com/news/indonesia/indianamalia/kasus-pekerja-migran-meningkat-inipenyebabnya- $1 / 3$. 
buildings, and $1 \%$ drivers. From this data, $19 \%$ experienced layoffs, $14 \%$ were unpaid, $10 \%$ trafficking victims, $6 \%$ document detention, $5 \%$ failed placement, $5 \%$ debt bondage, $4 \%$ fraud, $4 \%$ work not in accordance with the agreement, $3 \%$ abuse, $3 \%$ died, $3 \%$ over-stay, $2 \%$ imprisoned, $2 \%$ without procedure placement, 2\% lost contact, $2 \%$ extortion of persons, $1 \%$ falsification of documents, illness, depression and the death penalty. The Ministry of Women's Empowerment and Child Protection of the Republic of Indonesia stated that some migrant workers and their families experience problems, including a breakdown in household relationships. The relationship issue is mainly infidelity which leads to divorce and child neglect. Therefore, it causes problems with PMI child development. ${ }^{25}$ It is suspected that this lack of understanding has neglected the families of migrant workers and their child protection. But, on the other hand, it cannot be denied that family resilience is an essential part of building national strength.

There is still much injustice towards migrant workers. These injustice cases are violence/indecency, pending work protection cases, unknown technical procedures for resolving work relationship conflicts, and unilateral employer termination of employment are just a few of the many problems of Indonesian migrant workers. In addition, there are many reports on the results of studies and scientific writings which indicate that the deterioration of the fate of Indonesian migrant workers is due to one of the leading causes is the condition of PMI's legal illiteracy.

The level of education of Indonesian migrant workers also seems to have contributed to the vulnerability of Indonesian migrant workers. If you look at the data from the official BNP2TKI portal (now BP2MI), the Bank Indonesia Portal, the Word Bank Portal, and the www.sbmi.or.id portal (Year-End Notes), in 2019, as many as 101,440 or $36 \%$ of the number of employees Indonesian migrants have had a junior high school education or below. The low level of education is related to the general lack of knowledge and knowledge of the rights of Indonesian migrant workers in particular. Indonesian migrant workers who have low education are also more at risk of becoming unprocedural/illegal Indonesian migrant workers because they do not know where to look for correct information. Moreover, in the absence of legal documents, Indonesian migrant workers do not have the legal power to fight for their rights. According to data from the Directorate General of Immigration, it was noted, the overall total of illegal Indonesian migrant workers in 2019 reached more than 10 thousand people. These migrant workers primarily work in 5 sectors: the construction industry, oil and gas,

\footnotetext{
${ }^{25}$ Kementerian Pemberdayaan Perempuan dan Perlindungan Anak, "Lindungi Pekerja Migran Perempuan Dan Keluarganya," Publikasi dan Media Kementerian Pemberdayaan Perempuan dan Perlindungan Anak, 2018, https://www.kemenpppa.go.id/index.php/page/read/29/1946/lindungi-pekerja-migran .
} 
trade, agriculture, and household assistant services. The following shows data on various problems faced by Indonesian migrant workers.

Table 3. Indonesian Migrant Workers or Pekerja Migran Indonesia (PMI) Problem Patterns

\begin{tabular}{|c|c|c|}
\hline No & Types Of Problems & Total \\
\hline 1 & Overstay & 805 \\
\hline 2 & Unpaid Salaries & 660 \\
\hline 3 & Illness & 642 \\
\hline 4 & PMI request for return & 374 \\
\hline 5 & Communication termination & 87 \\
\hline 6 & $\begin{array}{l}\text { Termination of employment before the } \\
\text { end of the work agreement }\end{array}$ & 258 \\
\hline 7 & $\begin{array}{l}\text { The placement fee exceeds the fee } \\
\text { structure }\end{array}$ & 161 \\
\hline 8 & The occupation is not review compliant & 124 \\
\hline 9 & $\begin{array}{l}\text { Retention of passports or other documents } \\
\text { by PPTKIS }\end{array}$ & 90 \\
\hline 10 & $\begin{array}{l}\text { Retention of passports or other documents } \\
\text { by PPTKIS }\end{array}$ & 89 \\
\hline 11 & PMI failed to leave & 36 \\
\hline 12 & Human trafficking & 54 \\
\hline 13 & Illegal Recruit candidates & 46 \\
\hline 14 & Accident & 40 \\
\hline 15 & Failed Placement & 35 \\
\hline 16 & Violence from employers & 34 \\
\hline 17 & The workload is too heavy & 33 \\
\hline 18 & Subpar salary & 29 \\
\hline 19 & PMI in the custody process & 28 \\
\hline 20 & $\begin{array}{l}\text { Not sent home even though the work } \\
\text { contract is over }\end{array}$ & 26 \\
\hline 21 & $\begin{array}{l}\text { Inadequate (falsification of health } \\
\text { certificates or health checks are not } \\
\text { carried out) }\end{array}$ & 22 \\
\hline 22 & $\begin{array}{l}\text { The salary deduction exceeds the } \\
\text { provisions }\end{array}$ & 22 \\
\hline 23 & $\begin{array}{l}\text { Document falsification (KTP, diploma, } \\
\text { age, parental consent) }\end{array}$ & 21 \\
\hline 24 & $\begin{array}{l}\text { Accounts payable between CPMI and } \\
\text { PPTKIS }\end{array}$ & 21 \\
\hline
\end{tabular}

${ }^{26}$ Pelaksana Penempatan TKI Swasta or Placement Executives of Private Indonesia Migrant Workers 


\section{PMI had an accident}

21

It is believed that migrant workers from Indonesia need to get provisioning or education about the applicable laws in the destination country where they will work later. This is required so that Indonesian migrant workers avoid injustice when dealing with laws in other countries. ${ }^{27}$ Through adequate legal education, Indonesian migrant workers will also be protected from various problems as described above.

\section{Capacity Building for Indonesian Migrant Workers through Legal Literacy}

The various problems described above also show that legal literacy for Indonesian migrant workers is an urgent matter to increase their capacity. Therefore, in Article 6 paragraph (1) letter b of Law Number 18 of 2017 concerning the Protection of Indonesian Migrant Workers, education and training are regulated, which are rights to increase personal capacity. The Provincial and District/City Governments are responsible for organizing education and training in collaboration with accredited government-owned and/or private educational institutions and job training institutions. Moreover, they are accountable for providing and facilitating the training of Indonesian Migrant Workers Candidates through vocational training whose budget comes from the education function. Therefore, this regulation is normatively better than Law No. 39/2004 on the Protection of Indonesian Migrant Workers. Although, in the realm of practice, it is necessary to further ascertain whether the realization of education and training has met expectations.

Meanwhile, in the previous law, the realm of education and training was implementing private workers or job training institutions that had met the requirements. Wahyu Susilo stated that the provisions in the articles regarding education and training were just a theory in practice. The absence of synergy between education policies and labour policies has made the training process in preparing prospective Indonesian migrant workers seem arbitrary. It is common knowledge that the certificate of graduation is merchandise that can be bought and sold. The education and training curriculum for prospective migrant workers is indoctrinated, monologues, and far from participatory principles. Educational materials are also very gender-biased and keep students away from being critical and aware of their rights. ${ }^{28}$

Apart from this, the education and training still have a tiny portion of legal education and has not been optimal in its implementation. The need for Indonesian migrant workers for legal insight is enormous, both national labour

\footnotetext{
27 Putra Ananda, "Pekerja Migran Perlu Dapat Edukasi Hukum," Media Indonesia, 2020, https://mediaindonesia.com/read/detail/345200-pekerja-migran-perlu-dapat-edukasi-hukum. ${ }^{28}$ Wahyu Susilo, "Pendidikan Sebagai Agenda Perlindungan Buruh Migran Indonesia," 2016, https://migrantcare.net/wp-content/uploads/2016/09/artikel_JP_migran_dan_pendidikan.pdf .
} 
laws and laws of destination countries. The prevalence of legal blindness shows that the capacity of Indonesian migrant workers in the aspect of legal insight needs to be improved.

From the results of exploratory studies and experts' opinions on migrant workers (expert-judgment), the experts paid more attention to the importance of Pre-departure Training for migrant workers. The importance of Predeparture Education and Training has been handled by the Ministry of Manpower and educational agencies/institutions for migrant workers. Experts agree that although Predeparture Education and Training are essential, it is essential to provide access to education for migrant workers who have been abroad for work. From the research that has been done, it is obtained data that there are several competencies in the legal field required by Indonesian migrant workers, namely including 1) Introduction to Legal Studies, 2) Indonesian Legal System and destination countries, 3) Law and gender, gender issues and their protection in the destination country of work, 4) Cases of serious lawlessness, 5) National and destination country labour laws, 6) Law on proceeding imperatives of destination countries, 7) Communication and information networks of labour institutions/agencies/associations mediation-advocacy-consultations, 8) Immigration law, and 9) Family law and child protection. Meanwhile, from respondents' perspective regarding the competency needs, most migrant workers $(97 \%)$ responded positively and agreed to the existence of legal education for Indonesian migrant workers. Indonesian migrant workers see this legal education as needing self-capacity building, including increasing their bargaining position. ${ }^{29}$

\section{Legal Education for Indonesian Migrant Workers through Distance Education}

Looking at the link between the empowerment of Indonesian migrant workers on various problems caused by the inherent vulnerabilities of Indonesian migrant workers and legal insight that Indonesian migrant workers should master, legal education is necessary.

Legal education aims to increase the legal awareness of the community. If the community has legal awareness, the community will be aware and obedient to their rights and obligations as good citizens in carrying out the applicable law. Darwis R. formulated several vital matters related to the role of legal education in realizing legal awareness of Indonesian citizens, as follows, ${ }^{30}$ 1) Current status and positive legal values, 2) The effectiveness and efficiency of legal education through current formal channels, 3) There is a need for a critical review of the content or methods of legal teaching that have been and are currently being undertaken, 4) There is a need for a process

\footnotetext{
${ }^{29}$ Sri Wahyu K. dkk., "Pendidikan Hukum Jarak Jauh Dan Terbuka Bagi Pekerja Migran Indonesia," 2020.

${ }^{30}$ R. Darwis, Pendidikan Hukum Dalam Konteks Sosial Budaya Bagi Pembinaan Kesadaran Hukum Warga Negara (Departemen Pendidikan Indonesia: UPI, 2003). 
universal legal education, and 5) The importance of a dynamic strategy and legal contextualism. ${ }^{31}$

Legal education through distance education can be an alternative for Indonesian migrant workers. However, in principle, distance learning as a platform is an entity of the component values and education elements that provide a "barrier" in the teaching and learning process between tutors and their students. ${ }^{32}$ Distance learning is a form of teaching-learning model applied to students. It did not require face-to-face meetings (electronic tutorials/tutors) every time learning activities occur or what is referred to as single-mode of distance learning. However, the nomenclature of distance learning in theory and practice also recognizes the direct face-to-face teaching and learning process (face-to-face tutorial/TTM), limited by the number of TTM frequencies, which is called the Dual Mode of distance learning. In addition, there is an advanced distance learning method; one of them is the Blended-Mode of distance learning. This method integrates various tutorial models between Tuton-TTM-Printed Materials-Audio-Visual MaterialsComputer Assisted Instructional (CAI) and Integrated Above the Line-on the Line-below the Line.

Educational programs for Indonesian migrant workers using a distance learning education system or Sistem Pendidikan Belajar Jarak Jauh (SBJJ) platform can help limit the limitations of Indonesian migrant workers to obtain legal education without going through a face-to-face system. In addition, the legal education program for Indonesian migrant workers is also expected to be a communication medium for practitioners and relevant public officials to convey their ideas, ideas, and thoughts in developing the capacity of Indonesian migrant workers.

From the results of research conducted by Sri Wahyu et al. (2020), the majority of Indonesian migrant workers who were netted in the survey mentioned the education program model and essential competencies they needed in legal education with a distance education platform, namely from aspects 1) Impact of Education and Training, 2) Suitability of Training, 3) Specific competence, 4) Social Competence, 5) Other competencies, and 6) Opportunities for cooperation. Legal education and training will positively impact increasing their competence in the field of law that is directly related to their work and work environment, such as placing a better bargaining position in negotiating and contracting with their employers $(93 \%)$. The direct positive impact of the legal education and training program will affect their behavioural attitudes (96\%) and their daily work (91\%). Indonesian migrant workers also mentioned that if this legal education was held using the Distance

\footnotetext{
31 Sumaryati, "Urgensi Pendidikan Hukum Dalam Mewujudkan Kesadaran Hukum Masyarakat," in Konferensi Kewarganegaraan Ke-1 (Yogyakarta: Universitas Negeri Yogyakarta, 2015), 1-12.

32 Atwi Suparman, Desain Instructional, Pusat Antar Universitas (PAU) (Jakarta: Direktorat Jenderal Pendidikan Tinggi, Departemen Pendidikan Nasional, 1991).
} 
Learning platform, it would suit their needs (91\%), considering that Indonesian migrant workers have different working hours in each country where they work. Competency specifications required by migrant workers include: 1) Basic Working Skills (Household) 85\%, 2) Employment Relationships with Employers 100\%, 3) Migrant Legislation 100\%, 4) State Justice System 100\% Domicile, 5) Legal Aid Mechanism Procedure System $100 \%, 6)$ Power of attorney, letter of complaint, letter of response, letter of claim 100\%, 7) Contract \& Work Protection 100\%, 8) Insurance, issues of exit-permit and taxation of the country of domicile 100\%, 9) Terrorism, drugs, psychotropic drugs and Health 48\%, and 10) Ethical behaviour (rules of conduct) between the legal systems of the state of domicile $100 \%$. Meanwhile, the social competence needs of Indonesian migrant workers include, 1) Genderism 53\%, 2) 100\% Human Rights, 3) Intercultural Relationships, 44\% Domicile Countries, and 4) Criminal Sanctions between 100\% Domicile Countries. Apart from the legal education needs through distance education in the form of the competencies mentioned above, Indonesian migrant workers also need other competencies, namely 1) Women's Natural Rights at Work, 2) Legal Protection and Working Hours for Domicile Country migrant workers, 3) Entrepreneurship and IT Skills (Digital Marketing and Financial Management, 4) Attitude of Self-Control Behavior.

Distance education is a potential alternative in increasing the legal knowledge of Indonesian migrant workers. With the number of Indonesian migrant workers from 2014 to 2019 amounting to 1.55 million workers spread across various countries, distance education is reasonably practical. Besides looking at the Indonesian migrant workers' needs to fulfil their education, it will be accessible to Indonesian migrant workers wherever they are and tend to be flexible according to the working time of Indonesian migrant workers. Through this distance legal education, the hope is that the need for Indonesian migrant workers to have adequate legal knowledge will relieve them of vulnerabilities, both in the pre-employment, during work, and after-work stages.

\section{Conclusion}

Indonesian migrant workers need state intervention to protect the stage before work, work, and after work and equip themselves with adequate legal insights. The sound legal sense will increase the capacity of Indonesian migrant workers and will enable them to face any problems they face.

Legal literacy is an urgent matter to be "familiarized" with Indonesian migrant workers. Legal literacy will build awareness of Indonesian migrant workers in understanding various legal aspects, especially those related to the activities of Indonesian migrant workers. A decent understanding of the law certainly also increases the bargaining position of Indonesian migrant workers. The hope is that a fulfilling bargaining position will bring Indonesian migrant workers to a better condition. 
Distance education can be a way to increase the legal literacy of Indonesian migrant workers. Of course, with a design that can be obtained through indepth research on the various needs required by Indonesian migrant workers. Such distance education will bring improvement and benefit to Indonesian migrant workers.

\section{References}

Anak, Kementerian Pemberdayaan Perempuan dan Perlindungan. "Lindungi Pekerja Migran Perempuan Dan Keluarganya." Publikasi dan Media Kementerian Pemberdayaan Perempuan dan Perlindungan Anak, 2018. https://www.kemenpppa.go.id/index.php/page/read/29/1946/lindungipekerja-migran .

Ananda, Putra. "Pekerja Migran Perlu Dapat Edukasi Hukum." Media Indonesia, 2020. https://mediaindonesia.com/read/detail/345200pekerja-migran-perlu-dapat-edukasi-hukum.

Asrun, A. Muhammad. "Hak Asasi Manusia Dalam Kerangka Cita Negara Hukum (Catatan Perjuangan Di Mahkamah Konstitusi).” Jurnal Cita
Hukum
4, no.
(2016):
$133-54$.

https://doi.org/10.15408/jch.v4i1.3200.2016.4.1.133-154.

BBC. “'Penyiksa TKW' Di Malaysia Dibebaskan: 'Dia Mati Karena Disiksa', Indonesia Akan Terus Upayakan Keadilan Untuk Adelina." BBC News, 2019. https://www.bbc.com/indonesia/dunia-47996097 .

Dahlia. "Pelaksanaan Program Jamsostek Ditinjau Dari Perspektif Perlindungan Hukum Tenaga Kerja." Jurnal Wacana Hukum 11, no. 1 (2012): 83-94. https://doi.org/10.33061/1.jwh.2012.11.1.732.

Darwis, R. Pendidikan Hukum Dalam Konteks Sosial Budaya Bagi Pembinaan Kesadaran Hukum Warga Negara. Departemen Pendidikan Indonesia: UPI, 2003.

Databoks. "2014 - Maret 2019, Penempatan Pekerja Migran Capai 1,55 Juta," 2019. https://databoks.katadata.co.id/datapublish/2019/07/30/2014maret-2019-penempatan-pekerja-migran-capai-155-juta.

Eko Hartono. “Keterlaluan, Penyiksaan Oleh Majikan Perempuan': WNI Di Arab Saudi 'mata Disiram Air Klorin, Tangan Disetrika, Kemaluan Diinjak.” BBC News, 2020. https://www.bbc.com/indonesia/dunia53395540 .

Habibullah, Ahmad Juhari, and Lucy Sandra. "Kebijakan Perlindungan Sosial Untuk Pekerja Migran Bermasalah.” Sosio Konsepsia 5, no. 2 (2016): 66-77. https://doi.org/10.33007/ska.v5i2.178.

Haryono. "Globalisasi Dan Migrasi Tenaga Kerja Indonesia (Studi Deskriptif Sosiologi Kependudukan)." Hermeneutika: Jurnal Hermeneutika 3, no. 2 (2017): 1-13. https://doi.org/10.30870/hermeneutika.v3i2.3084.

International Labor Organization (ILO). "Perlindungan Dan Pencegahan Untuk Pekerja Migran Indonesia,” 2006. 
https://www.ilo.org/jakarta/whatwedo/publications/WCMS_122318/lan g--en/index.htm.

International Organization for Migration (IOM). "Migrasi Tenaga Kerja Indonesia, Gambaran Umum Migrasi Tenaga Kerja Indonesia Di Beberapa Negara Tujuan Di Asia Dan Timur Tengah," 2010. https://www.iom.int/jahia/webdav/shared/shared/mainsite/published_d ocs/Final-LM-Report-Bahasa-Indonesia.pdf.

Judge, Zulfikar. "Perlindungan Hukum Bagi Tenaga Kerja Indonesia Di Luar Negeri." Lex Jurnalica 9, no. 3 (2012): 171-75. https://ejurnal.esaunggul.ac.id/index.php/Lex/article/view/347.

K. dkk., Sri Wahyu. "Pendidikan Hukum Jarak Jauh Dan Terbuka Bagi Pekerja Migran Indonesia," 2020.

Koesrianti. "Pelindungan Hukum Pekerja Migran Penata Laksana Rumah Tangga (PLRT) Di Luar Negeri Oleh Negara Ditinjau Dari Konsep Tanggung Jawab Negara." Yustisia 4, no. 2 (2015): 245-68. https://doi.org/10.20961/yustisia.v4i2.8642.

Malia, Indiana. "Kasus Pekerja Migran Meningkat, Ini Penyebabnya." IDN

Times, 2018.

https://www.idntimes.com/news/indonesia/indianamalia/kasus-pekerjamigran-meningkat-ini-penyebabnya-1/3.

Mulyana, W., and Marjuki. "Penanganan Tenaga Kerja Indonesia Bermasalah Melalui Rehabilitasi Psikososial Dan Pemberdayaan Sosial." Kementerian Sosial, 2015. https://www.kemsos.go.id/modules.php?name=News\&file=article \&sid $=18580$.

Purnomo, Didit. "Fenomena Migrasi Tenaga Kerja Dan Perannya Bagi Pembangunan Daerah Asal: Studi Empiris Di Kabupaten Wonogiri." Jurnal Ekonomi Pembangunan 10, no. 1 (2009): 84-102. https://doi.org/10.23917/jep.v10i1.810.

Raharto, Aswatini. "Pengambilan Keputusan Tenaga Kerja Indonesia (TKI) Perempuan Untuk Bekerja Di Luar Negeri: Kasus Kabupaten Cilacap." Jurnal Kependudukan Indonesia 12, no. 1 (2017): 39-45. https://doi.org/10.14203/jki.v12i1.275.

Ratihtiari, A. A. Titah, and I Wayan Parsa. "Perlindungan Hukum Terhadap Pekerjamigran Indonesia Di Luar Negeri." Kertha Semaya 7, no. 7 (2019): 1-15. https://doi.org/10.24843/KM.2019.v07.i07.p02.

Saroinsong, W. "Penanganan Masalah TKI Ilegal Oleh Pemerintah RI." Indonesian Journal of International Law 5, no. 4 (2008): 833-57. http://ijil.ui.ac.id/index.php/home/article/download/483/pdf_367.

Sepriandi, Sigit. "Kebijakan Perlindungan Sosial Bagi Pekerja Migran Bermasalah (PMB) Di Debarkasi Kota Tanjungpinang." Kemudi: Jurnal Ilmu Pemerintahan 2, no. 2 (2018): 79-102. https://ojs.umrah.ac.id/index.php/kemudi/article/view/760.

Solechan, Tri Rahayu Utami, and Muhamad Azhar. "Upaya Meningkatkan 
Jaminan Perlindungan Pekerja Migran Indonesia." Administrative Law \& Governance Journal 2, no. 1 (2020): 153-61. https://doi.org/10.14710/alj.v3i1.153-161.

Suhartoyo. "Prinsip Persiapan Penempatan Dan Perlindungan Tenaga Kerja Indonesia Di Luar Negeri." Adminitrative Law \& Governance Journal 2, no. 3 (2019): 523-40. https://doi.org/10.14710/alj.v2i3.523-540.

Sumarsono, Grace Ester Caroline Korompis, and Diana Vanda D. Doda. "Pengaruh Edukasi Melalui Literasi Hukum Terhadap Tindakan Pencegahan Medical Error Pada Perawat Di Rumah Sakit." Indonesian Journal of Public Health and Community Medicine 1, no. 4 (2020): 3339. https://ejournal.unsrat.ac.id/index.php/ijphcm/article/view/31205.

Sumaryati. "Urgensi Pendidikan Hukum Dalam Mewujudkan Kesadaran Hukum Masyarakat." In Konferensi Kewarganegaraan Ke-1, 1-12. Yogyakarta: Universitas Negeri Yogyakarta, 2015.

Suparman, Atwi. Desain Instructional, Pusat Antar Universitas (PAU). Jakarta: Direktorat Jenderal Pendidikan Tinggi, Departemen Pendidikan Nasional, 1991.

Susilo, Wahyu. "Pendidikan Sebagai Agenda Perlindungan Buruh Migran Indonesia," $2016.2 \mathrm{https} / /$ migrantcare.net/wpcontent/uploads/2016/09/artikel_JP_migran_dan_pendidikan.pdf .

Widodo, Hartono, and R. Jossi Belgradoputra. "Perlindungan Pekerja Migran Indonesia." Binamulia Hukum 8, no. 1 (2019): 107-16. https://doi.org/10.37893/jbh.v8i1.42. 
